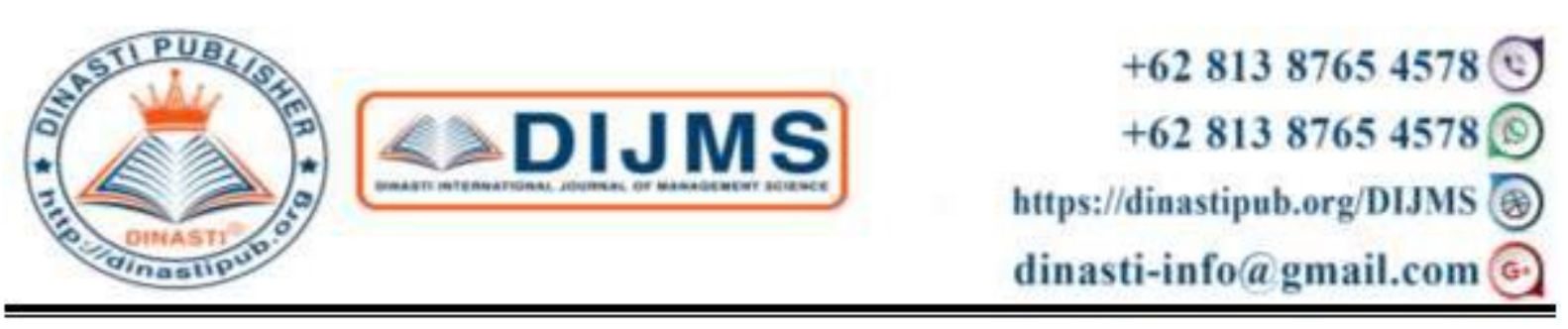

\title{
ANALYSIS OF CONSUMER PERCEPTIONS OF SERVICE QUALITY OF DRINKING WATER COMPANIES
}

\author{
${ }^{1)}$ Handry Sudiarta Athar, ${ }^{2)}$ Himawan Sutanto, ${ }^{3)}$ Iwan Kusmayadi \\ Postgraduate degree, Mataram University, Lombok, Indonesia
}

\section{ARTICLE INFORMATION}

Received: 20 February 2020

Revised: 02 March 2020

Issued: 09 March 2020

(filled in by Editor)

Corresponding author: first author

E-mail:

andre_sudiartha@yahoo.com

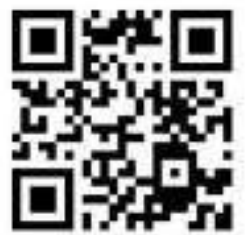

DOI:10.31933/DIJMS
Abstract:

The aim of the research was to analyze the service quality of drinking water companies using the servQual method. This research is a quantitative research with research method conducted in different companies in the city of Mataram, Lombok. Data analysis was performed using the service quality method (ServQual). The results showed that the customer satisfaction criteria on each service characteristic in general of the five components were on average very good, this is known from the results of the NKJ calculation which are results 1,022 that are classified as very good.

Keywords: Consumer Perception, Service Quality, Company

\section{INTRODUCTION}

Competition will be achieved if the company can create and retain customers (Tjiptono, 2008). To achieve these objectives, the company requires different efforts to achieve the planned objectives. An effort that needs to be made is to improve the quality of business services. Good business quality will meet customer expectations through services that come with the products offered with the aim of creating customer satisfaction (Kotler, 2005). Service quality is one of the survival requirements of a company or agency, the high quality of the services provided will be reflected in the aspect of service user satisfaction (Suryaningtyas, et al. 2013).

Satisfied customers are opportunities to get new customers. Customer satisfaction is a very important part in the success of a company (Winarno and Absor, 2018). Retaining all existing clients will generally be more profitable than changing clients, because the cost of attracting new clients can be five times as high as retaining an existing client (Kotler, 2005), thus retaining Customers is the same as maintaining the viability of the business. 
Customer satisfaction research in Lombok, West Nusa Tenggara Regency is urgently needed to prevent the number of consumers from decreasing in the coming period and reducing the negative impact of dissatisfied customers serving the company. One method that can be used to assess customer satisfaction in a company is the Servqual method (Parasuraman, et al., 1988). The Servqual method is the most popular service quality method and has been used as a reference in developed management research and service marketing (Parasuraman, et al. In Tjiptono 2008). This method can measure service quality and can be used to analyze the causes of service problems. The quality of the services provided may not meet the expectations of the consumer, or is in accordance with the expectations of the consumer or even the services provided exceed the expectations of the consumer. This can be analyzed by looking at differences between the perception of service providers and consumer expectations. The score on this gap represents the value of service quality or Servqual value.

The need for clean water is a basic need that all people must meet to support their lives (Andini, 2017). The provision of clean water must be provided by the community itself or must be provided by the state as a condition to protect and prosper people. According to their authority, each region must carry out activities aimed at providing services to the community, in particular services based on basic needs, namely the need for clean water. Government efforts and efforts are solely for activities that cannot be carried out by the private sector or the community itself.

\section{LITERATURE REVIEW}

\section{Quality of service}

Marketing is that one can assume that there will always be a need for sales. Quality is a dynamic condition with regard to products, services, people, processes and the environment that meets or exceeds expectations (Yamit, 2005). Quality is the general characteristics and nature of a product or service that influences the ability to meet the stated or implicit needs of Kotler (2005).

Service quality is a statement of attitude, the relationship that results from the comparison between expectations and performance (results) (Wastranu, 2014). Service quality is an attempt to meet customer needs and wishes, as well as the accuracy of delivery to balance customer expectations (Tjiptono, 2005). Lahi Tjiptono (2005) states that the quality of service consists of the expected level of excellence and control over the level of excellence to meet customer needs.

Quality must start with the needs of the customer and end with the customer's perception. This means that a good-quality image is not based on the point of view or perception of the service provider, but on the perspective or perception of the customer. It is the customer who determines whether a service is quality. Whether or not the quality of the service depends on the ability of service providers to consistently meet their customers' expectations

\section{Service Quality (ServQual)}

There are 5 dimensions of service quality, namely tangible issues, reliability, responsiveness, certainty, empathy (Parasuraman et al., 1990). Service quality evaluation using the ServQual model involves calculating the difference between the values given by customers for each pair of statements regarding expectations and perceptions. ServQual scores for each pair of statements, for each customer can be calculated based on the following formula (Zeithaml, et al, 1990 in Tjiptono 2008).

The most popular service quality model and to date has been used as a reference in management research and service marketing, namely the ServQual model (abbreviation for service quality) developed by parasuranman, Zeithaml and Berry in their series of 
investigations into six service sectors. The model, also known as the Gab analysis model, is closely related to customer satisfaction based on the design for unconfirmation.

The ServQual model is widely used in various companies and industrial contexts. The popularity of the ServQual survey is due to a number of advantages. Firstly, the ServQual instrument has developed into a kind of standard for assessing different dimensions of service quality. Secondly, various studies have shown that the ServQual instrument is valid for different service contexts. Thirdly, research also indicates that the ServQual questionnaire is reliable, which means that the questions are interpreted equally by different respondents. Fourth, the ServQual instrument meets the parsimony criteria, because it consists of only 22 items, so that it can be filled in quickly by respondents. Fifth, the ServQual instrument has standard analysis procedures that facilitate the interpretation of results (Wijaya, 2011).

\section{RESEARCH METHODS}

This study uses the ServQual method (service quality) as developed by Parasuraman et al (1994). ServQual is carried out at a drinking water company in the city of Mataram and the number of samples is 40 consumers. Primary data is data obtained directly from customers who call in the city of Mataram in the form of answers to questions in the questionnaire. Secondary data is data obtained from informants or literature related to this research.

The methods and tools used in this study have been adapted from questionnaires developed by Parasuraman et al (1994) and Dursun et al (2014). The questionnaire represented 5 dimensions of service quality, namely tangible, reliability, responsiveness, certainty and empathy. Each item is presented in two models, namely consumer perception and aspects of consumer expectations, and then compared. If the quality of the service received meets the above expectations or expectations, it can be concluded that the service is of good quality and vice versa.

\section{FINDINGS AND DISCUSSION}

With the growing need for clean water from the community, it is developing rapidly. To illustrate the drinking water company over the development of the last five years with regard to the number of consumers and the number of company sales, the table below is presented.

Table 1. Developments in the number of consumers and the number of sales and percentages of 2015-2019 in the city of Mataram

\begin{tabular}{ccccc}
\hline Year & $\begin{array}{c}\text { Growth in Number of } \\
\text { Customers }\end{array}$ & $\begin{array}{c}\text { Percent Increase in } \\
\text { Number of Customers }\end{array}$ & $\begin{array}{c}\text { Percentage of } \\
\text { Development of Sales } \\
\text { Amount }\end{array}$ & $\begin{array}{c}\text { Incease in Sales } \\
\text { Amount }\end{array}$ \\
\hline 2015 & 11.634 & - & 7.827 .212 .360 & - \\
\hline 2016 & 12.705 & $20,82 \%$ & 8.870 .407 .105 & $16,40 \%$ \\
\hline 2017 & 13.068 & $21,42 \%$ & 9.748 .996 .675 & $18,03 \%$ \\
\hline 2018 & 11.631 & $19,06 \%$ & 9.968 .153 .640 & $18,43 \%$ \\
\hline Total & 11.967 & $19,62 \%$ & 17.665 .042 .025 & $32,66 \%$ \\
\hline Average & 61.005 & $67,51 \%$ & 54.079 .811 .805 & $73,55 \%$ \\
\hline Sour & 12.201 & $20 \%$ & 10.815 .962 .361 & $20 \%$ \\
\hline
\end{tabular}

Source: Drinking Water Companies in Mataram (primary data processed), 2019

On the basis of the table above, the development of the number of consumers of drinking water companies in the city of Mataram can be seen for five years, with a total of 61,005 people with an average percentage increase of $20 \%$ per year. Similarly, the number of sales of drinking water companies in the city of Mataram has always increased over the past five years with a total turnover of Rp 54,079,811,805 or an average increase in income of 
$20 \%$ per year. The increase that took place was due to increased rates and a greater number of customers, both not only because of the quality of service provided by drinking water companies in the city of Mataram, but rather because of the awareness of the need of the community to increase the needs of clean water in combination with the nature of the activities of drinking water companies in the monopolistic city of Mataram.

As a water supply company whose main purpose is to provide services to the community, it is necessary to conduct an investigation into the extent to which consumers experience the quality of water companies in the city of Mataram. The company wants to provide the community with services that are needed to improve the quality of service to improve the consumer. Data on the expectations and actual performance of drinking water companies in the city of Mataram in each element of the existing services are described in Table 2 in order to make a comparison between the total scores of each service characteristic, so that the NKJ analysis is used.

\section{Table 2. Criteria for conformity between expectations and current performance of the drinking water companies in Mataram District}

\begin{tabular}{|c|c|c|c|c|c|}
\hline No. & Service Attributes & $\begin{array}{c}\text { Total } \\
\text { Performance } \\
\text { Score } \\
\end{array}$ & $\begin{array}{l}\text { Total expected } \\
\text { score }\end{array}$ & NKJ & Category \\
\hline \multicolumn{6}{|c|}{ Tangibels } \\
\hline 1 & $\begin{array}{l}\text { Facilities that form a series of services such } \\
\text { as faucets, pipes, and other spare parts. }\end{array}$ & 129 & 124 & 1,04 & Very Good \\
\hline 2 & Physical proof of water given to consumers & 125 & 121 & 1,03 & Very Good \\
\hline 3 & Call center services. & 142 & 120 & 1,18 & Very Good \\
\hline 4 & $\begin{array}{l}\text { Installation of new water installation } \\
\text { services. }\end{array}$ & 121 & 128 & 0,94 & Not good \\
\hline 5 & Number of payment counters. & 125 & 123 & 1,02 & Very Good \\
\hline \multicolumn{6}{|c|}{ Reliability } \\
\hline 1 & $\begin{array}{l}\text { Suitability of services in accordance with the } \\
\text { promises made and agreed by both parties }\end{array}$ & 121 & 120 & 1,01 & Very Good \\
\hline 2 & $\begin{array}{l}\text { The smooth working system of drinking } \\
\text { water companies's to meet the needs of } \\
\text { consumers. }\end{array}$ & 121 & 120 & 1,01 & Very Good \\
\hline 3 & Attention to complaints against consumers. & 123 & 127 & 0,96 & Not good \\
\hline 4 & $\begin{array}{l}\text { The sense of consumer safety for the service } \\
\text { facilities it receives. }\end{array}$ & 128 & 122 & 1,05 & Very Good \\
\hline 5 & A competent payment process & 124 & 128 & 0,96 & Very Good \\
\hline \multicolumn{6}{|c|}{ Responsiveness } \\
\hline 1 & $\begin{array}{l}\text { Employees who are able to perform tasks in } \\
\text { serving customers. }\end{array}$ & 125 & 122 & 1,03 & Very Good \\
\hline 2 & $\begin{array}{l}\text { Readiness of employees who perform tasks } \\
\text { in serving consumers. }\end{array}$ & 128 & 122 & 1,03 & Very Good \\
\hline 3 & Dissemination of information to consumers. & 128 & 122 & 1,05 & Very Good \\
\hline 4 & $\begin{array}{l}\text { Dissemination or outreach activities with } \\
\text { regard to drinking water companies policy }\end{array}$ & 123 & 122 & 1,01 & Very Good \\
\hline 5 & $\begin{array}{l}\text { Service operational time is according to the } \\
\text { customer. }\end{array}$ & 121 & 121 & 1 & Not good \\
\hline \multicolumn{6}{|c|}{ Assurance } \\
\hline 1 & $\begin{array}{l}\text { Physical protection of water against facilities } \\
\text { used by consumers. }\end{array}$ & 124 & 121 & 1,03 & Very Good \\
\hline 2 & $\begin{array}{l}\text { Consumer security with regard to installation } \\
\text { services. }\end{array}$ & 124 & 122 & 1,02 & Very Good \\
\hline 3 & A clear officer identity & 124 & 121 & 1,03 & Very Good \\
\hline 4 & Open service process & 124 & 121 & 1,03 & Very Good \\
\hline 5 & Socializing drinking water companies policy & 140 & 121 & 1,16 & Very Good \\
\hline \multicolumn{6}{|c|}{ Emphaty } \\
\hline 1 & Alternative solutions to consumer problems. & 121 & 122 & 0,99 & Very Good \\
\hline 2 & $\begin{array}{l}\text { Understand the needs of the consumer in } \\
\text { accordance with the expectations of the }\end{array}$ & 121 & 124 & 0,97 & Very Good \\
\hline
\end{tabular}




\begin{tabular}{|c|c|c|c|c|c|}
\hline No. & Service Attributes & $\begin{array}{c}\text { Total } \\
\text { Performance } \\
\text { Score } \\
\end{array}$ & $\begin{array}{l}\text { Total expected } \\
\text { score }\end{array}$ & NKJ & Category \\
\hline \multicolumn{6}{|c|}{ consumer. } \\
\hline & Average & 2.740 & 2.681 & 1,022 & Very Good \\
\hline
\end{tabular}

Table 2 shows that the criteria for customer satisfaction on each service characteristic are generally very good of the five components, this is known from the results of the NKJ calculation, which are 1,022 results that are classified as very good. In detail, where from table 2 are attributes that have poor results, namely the direct evidence attribute in the form of installation of new installation services and the reliability attribute in the form of complaints of complaints to consumers, competent payment processes and empathy attributes in the form of alternative problem solving and understanding of consumer needs in line with consumer expectations. Regarding the five characteristics above, apart from empathy, the quality is very good, so the company must continue to work on improving consumer services. The drinking water company in the city of Mataram must therefore pay attention and must immediately make improvements or not be repaired, will be known by Cartesian diagram analysis.

For a clearer description of the status of the drinking water company in Mataram city in the provision of services, these must actually be analyzed using the Cartesian diagram in Figure 1, so that the service characteristics that have priority.

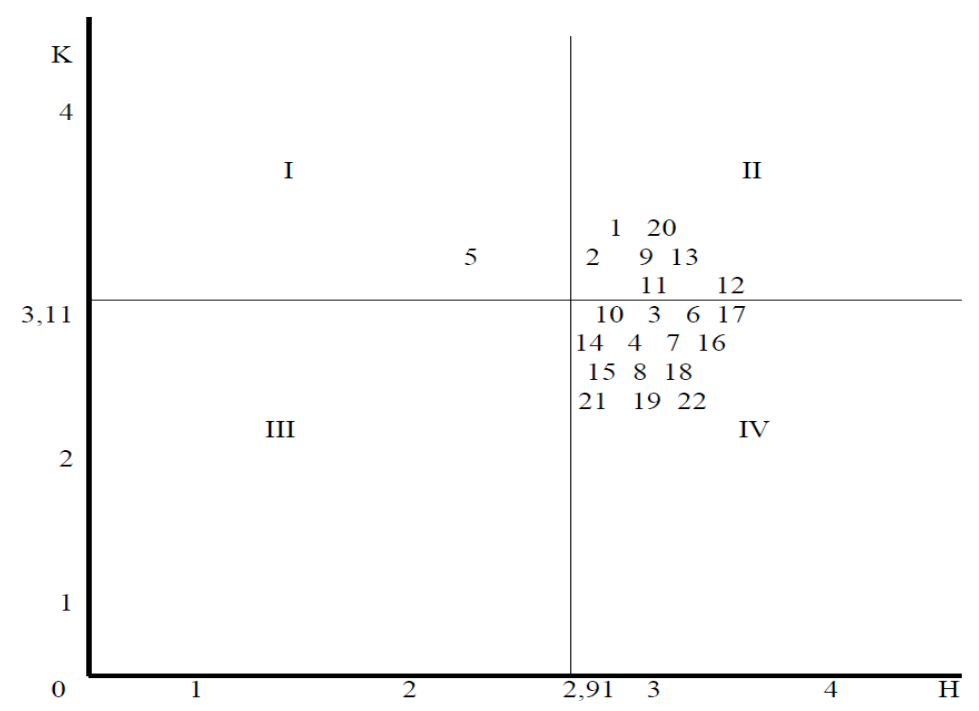

Figure 1. Plot / Cartesian diagram of performance (K) and expectation (H) of 22 service features

In the picture in quadrant $I$ there is one service feature that is considered less important by consumers, but that is fairly well presented by the manager of a drinking water company in the city of Mataram in question, namely the smooth working system of a drinking water company to meet the needs of to satisfy the consumer.

In Kudran II there are five service features that consumers consider very important and the manager presents it fairly well. Where these attributes include the facilities in the range for performing services such as faucets, pipes and other spare parts, physical evidence of water provided to consumers, the consumer's feeling about the service facilities they receive, employees who have the opportunity to perform tasks in serving consumers, the willingness of employees to fulfill their duties in serving consumers, disseminating information to consumers, as well as socializing the policies of drinking water companies in the city of Mataram. While in quadrant III none of the attributes fall into this category.

In the last quadrant, which is quadrant IV, there are 14 attributes that are poorly presented but are considered very important by consumers, namely call center services, installation of new water installation services, suitability of services in accordance with 
promises made and agreed by both parties, smooth work system of water companies drinking in the city of Mataram to meet consumer needs, attention to complaints against consumers, employees who are able to fulfill the task of serving consumers, socialization or outreach activities related to the policy of drinking water companies, operational time of service in accordance with consumers, physical safety of water against facilities used by consumers, consumer security of the installation service, clear self-identification of officers, open service processes, alternative solutions to problems that consumers faces, as well as insight into the needs of the consumer in accordance with the expectations of the consumer.

After seeing the calculation results of each consumer perception formed in the score method and the frequency table, the results can be shown that the consumer perception is good. Where offering all existing attributes is good with a Service Quality Value of 1,022 of the average number of respondents. This proves that offering all existing programs is good with a service quality value of 1,022 of the average number of respondents. This proves that the drinking water company in the city of Mataram has a positive image in the eyes of its consumers, because although there are still complaints and perceptions that are not good from the respondents, it can still be tolerated

\section{CONCLUSION AND SUGGESTION}

Based on the results of the study, it can be concluded that the customer satisfaction criteria for each service characteristic are generally very good among the five components, this is known from the results of the NKJ calculation, the results of which are 1,022 are properly classified.

\section{REFERENCES}

Andini, R, Mega Ulimaz, M., Sulistijono. 2017. Evaluation of water supply performance in Baru Ulu district, West Balikpapan district, Balikpapan city, Journal of Regional and Rural Development Planning, 1(3). Pp. 307-316 DOI: http://dx.doi.org/10.29244 ljp2wd.2017.1.3.307-316

Dursun, T, Oskaybas, K. and Gokmen, C. 2014. Perceived quality of distance education from the user perspective. Contemporary Educational Technology, 5(2), pp. 121-145

Kotler, P, \& Karen F.A. Fox. 2005. Strategic Marketing for Educational Institutions. New Jersey: Prentice Hall Ince.

Parasuraman, A., Zeithaml, V.A., and Berry, L.L. 1994. Reassessment of expectations as a comparison standard in measuring service quality: Implications for future research. Journal of Marketing, vol. 58, pp. 111- 24.

Tjiptono, F. 2005. Service Quality and Stativication. Yogyakarta: Andi Offset.

Tjiptono, F. 2008. Service Management, Second Edition. Yogyakarta: Andi Ofset.

Wastranu, I.K., Wahyuni, C.R., Liansari, G. P. 2014. Proposed Improvement of the Quality of Service in Higher Education X Using the Service Quality (ServQual) method. Integra Maker. 1 (2). pp. 180-192.

Wijaya, T. 2011. Service quality management. Jakarta: PT index 
Winarno, H., Absor, T.B. 2018. Analysis of service quality with service quality (ServQual) and importance of performance analysis (IPA) methods in PT. Media Full Engineering. Journal of Industrial and Logistics Management. 1 (2). pp. 146-160

Yamit, Z. 2005. Quality management of products and services Yogyakarta: FE UII Yogyakarta. 